makroléptékü vizsgálati módszereket alkalmaz a szerzö. Megállapítása szerint az emberi települések - különösen a nagyvárosok okozta környezetváltozás hatása mindhárom szférában jelentôs. Rámutat arra, hogy a közlekedési pályák épitése viszonylag kis területsávon, de annál számottevőbb anyagkicserélődéssel járt. Kiemeli, hogy a mezôgazdaság különbözó ágai (a szólómúvelés, birkalegeltetés és a földmúvelés, stb.) különböző kitettségú helyeken, más-más módon, de mégis komplexen hatnak a lejtók lepusztulására és a korrelativ üledékek felhalmozódására. Feltétlenül figyelemre méltó a terület határvonalait képező Duna és Dráva hosszának felére csökkenése és az, hogy az utóbbi évtizedekben már ezen a területen találjuk a hazai halastavak és víztározók közel egyharmadát.

A negyedik fejezet - a szintézis - az antropogén hatások föbb jellegzetességeinek a leírásával kezdődik. Fontos megállapitás, hogy mindenfele antropogén beavatkozás a "társadalmi-gazdasági alakulat igényein ek megfelelóen alakul'. Területenként rendszerezi az antropogén folyamatokat és azok következményeit. Kár, hogy a szintézisben tényszerû̉en közölt, feltehetóen becslés alapján történt megállapításokat nem fejti ki bóvebben, igy ezek megértése nehézséget okoz.

Végül a PÉCSI M--SOMOGYI S.-JAKUCS P. által 1972-ben közölt tájtipológiai rendszer bontásával az antropogén hatások komplex területi típusait ökológiai alapokra épülő rendszerbe foglalja.

A könyvet hét oldalnyi forrásmunka és közel 30 oldalas függelék zárja, amely tartalmazza az egyes ábrákhoz tartozó jelkulcsokat is.

E gazdagon illusztrált, nagy adatbázisra épülő, az ismereteket jól rendszerező, korszerú mondanivalójú átfogó munkát a környezeti problémák iránt érdeklődô olvasók, kutatók, területi tervezók és földrajztanárok egyaránt haszonnal forga thatják.

CSORDÁS LÁSZLO

\title{
GEMEINDEN IN DER WIRTSCHAFTSPOLITIK
}

(Krista West szerk.)

(A kommunális pénzügy-és gazdaságpolitika lehet6ségei és korlátai lassuló gazdasági növekedés mellett. Kommunalwissenschaftliches Dokumentationszentrum. Wien, 1985. 98 p.)

A bécsi Kommunalwissenschaftliches Dokumentationszentrum (KDZ) kiadványainak sorát gazdagítja a fenti címet viseló könyvecske. Az Intézet fennállásának 15 éves évfordulója adott alkalmat a konferencia megrendezésére, majd az ott elhangzott elöadások egy kötetben történó megjelentetésére. Ausztria és a Német Szövetségi Köztársaság szövetségi, illetve községi vezetôi, valamint a téma elméleti szakemberei gyültek össze. A tanácskozás témája a községnek 1 a helyi és az állami gazdaságpolitikában betöltött szerepe volt. A téma idószer úségét - úgy vélem - nem szuikséges külön indokolni. Éppen ezért helyénvalónak érzem a magyar viszonyokkal való öszszevetést és némi kitekintést.

Az elöadások elméleti kiindulópontja a köz- ségek, mint helyi önkormányzatok pénzügyi és egyúttal gazdaságpolitikai mozgásterének a hetvenes évektól kezdôdó, majd a nyolcvanas években fokozódó beszúk ülése.

Az előadók többsége a krízishelyzet kia lakulását az olajárrobbanások idópontjához kötötte. Napjainkra pedig Keleten és Nyugaton is jellemzóvé vált a helyi bevételi források apadása, anélkül, hogy a helyi feladatok csökkentek volna.

A szerzók a községek pénzügyi mozgástere visszaszerzésének lehetőségeit kutatják; érzékelik mind szövetségi, mind regionális viszonylatban a területi különbségek elmélyülését; vizsgálják - megváltozott feltételek között a községi szolgáltatások és a gazdasági támogatási rendszer helyzetét; taglalják a foglal- 
koztatáspolitikai gondokat, illetve a munkaerôpiac kérdéseit; s keresik a megoldást, miként állitható a területi tervezés, mint eszköz a takarékosság szolgálatába. A KDZ kiadványa komplex szemléletével a községet nem szakítja ki a nemzetgazdaság egészéből, sôt az azzal való kölcsönhatásra koncentrál. A tôkés központi gazdaságpolitika hármas feladatkörének megvalósításában - a növekedési - és struktúrapolitikában, a foglalkoztatást stabilizáló politikában, valamint az elosztási politikában - lényegi szerepet jelöl ki a községek számára.

A német, illetve osztrák község esetében adottnak kell vennünk az önkormányzatiságot, ameiyet hazai megfelelôje a tanács, hoszszú ideje csak töredékesen tudott megvalósítani. Ott ez többet is, mást is takar. A község, város vagy éppen községszövetség mint vállalkozó, mint munkaadó és mint szubvencionáló saját jogok gyakorlója. Ătfogó kommunális pénzügyi autonómia alanyaként ellátási feladatait és infrastrukturális beruházásait decentralizáltan maga tervezi, finanszírozza és hajtja végre. Paradox módon a gazdaságilag magasan fejlett államokban éppen a községek növekvő gazdasági és társadalmi kiterjeszkedése cáfolja meg a teljesen autonóm községi pénzügyi politika lehetőségét. Weisbrod ${ }^{2}$ szerint az említett autonómia korlátját jelenti, hogy a decentralizált döntés az eliátás hiányosságaihoz vezet. Ez annak feitételezésébö1 ered, hogy a községek a maximális jólétre törekedve infrastruktúra-politikájukat úgy alakítják, hogy az intézmények maximális kihasználtsága a beruházások határköltségének feleljen meg. Azáltal, hogy nemcsak a község saját lakosai veszik igénybe a szolgáltatásokat, a használat a községen túlra terjed. Mivel e használati exporttal nem áll szemben import, ezért a beruházáso $k$ hatékonysága, a teljeskörü ellátottság szemszögébői az optimum alá csökken.

A német önkormányzatiság fogalmát még annyiban szükséges kiegészíteni, hogy a Német Szövetségi Köztársaság alkotmánya - intézményes garanciák biztosításával - a helyi kö. zösségek minden ügyét a községek saját döntési jogkörébe utalja. Az NSZK azon kevés államok közé tartozik, mely a helyi szint felett egy további önkormányzati szintet ismer, ez a járás. İy állhat elő az a sajátos helyzet, hogy a járás bizonyos, a községek által megvalósíthatatlan helyi feladatokat teljesítsen. Ezzel elker ülhetố egyes feladatok tełjes elhanyagolása, illetve az is, hogy azokat kizárólag az állam lássa el a jövóben. ${ }^{3}$

A következőkben az általam legfontosabbnak ítélt gondolatok felvillantására szorítkozom, nem is vállalkozva arra, hogy részleteiben visszaadjam a kötet tartalmát.

Ewald Nowotny (a bécsi Wirtschaftsuniversităt professzora) cikke a községi szolgáltatások átstrukturálódásával foglalkozik, elsősorban a nagy és köze pes méretû községeket érintve. A kommunális beruházások terén kísérteties a hasonlóság a magyar viszonyokkal. Az e szférába eső beruházások döntő hányada Magyarországon a tanácsokat terhelte és terheii, csakúgy, mint az NSZK-ban, ahoi $53 \%$-os a községek részesedése. Az utóbbiak inveszticiós kvótája 1982-ben reálértékben egyharmaddal alatta maradt az 1975-ös évinek. Hazánkban pedig 1978 elejétôl - a beruházási feszültségek enyhítésére - bevezettük a beruházási színvonal-szabályozást, majd az új tervidőszak kezdetétől, még mindig azonos céllal, a forrásszabályozásra tért ünk vissza.

$\mathrm{Az}$ elốadó állásfoglalása szerint a községi kiadások csökkenése a szúk pénzügyi keresztmetszettel magyarázható, ső́t a községek sok esetben elérték eladósodási határukat. A tanulmányban ismertetett megoldások közül figyelemre méitó - amit többen érintettek a tanácskozáson -, az erôsen instabil, a konjunktúraalakulástól függô ipari adó felváltása egy jövedelemtől független, biztonságosabb költségvetési bevételt nyújtó adóval. Egy még kidolgozás alatt álló, új adóformáról esett szó, a termelési érték adóról, mely vagy az eredetelv szerinti forgalmi adó, vagy a jövedeiemadó analógiájára lesz megfoga Imazható.

Érdemes a forrás-oldal mellett a kiadásokra is egy pillanatást vetnünk. Német-osztrák viszonylatban a gazdasági támogatás ellenkező elöjellel vetôdik fel, mint tanácsainknál. "Ott" e kifejezés a községek aktív gazdaságpolitikáját szolgáló sokirányú eszköztárat takarja. A gazdasági támogatás klasszikus célja, hogy a község az újonnan telepítendő üzemeket kedvező támogatásajánlattal telephely ük megválasztásában befolyásolja, azaz saját közigazgatási területére vonzza. Igy tudja a helyi üzemi és gazdasági struktúrát a lakítani és a foglalkoztatást biztosítani, továbbá, elsôdlegesen az üzemi adókból táplálkozó gazdasági erejét fokozni. A KDZ tudományos munkatársának, 
Tilman Brandlnak a megállapitása, hogy e célok egyre hiányosabban valósulnak meg. A megváltozott keretfeltételek az ủj üzemalapítási, illetve -telepítési potenciált csökkentették, kihatásaként kiéleződött a telephelykonkurrencia. (Az utóbbin az értendô, hogy az új telephelyekért a községek közel azonos feltételek, infrastrukt urális adottságok mellett versengnek, azaz e téren még nem jött létre a specializáció.) A gazdasági támogatáspolitikára nézve ennek biztos következményei adódnak. Valamennyi község célja egy modern és versenyképes gazdasági struktúra kialakítása, és az ún. csúcstechnológia bevezetése. E fejlődés pedig új szakmai követelményeket támaszt a községek gazdasági politikájával szemben. Brandl a községi szinten fennálló berendezkedés részbeni újraorientálását javasolja. Eszerint a községek feladatai a vállalkozások irányában a következók lennének:

pl.

- technológiai - és piacvonatkozású információk beszerzése és közvetítése;

- lehetőleg átfogó támogatási-, szerviz-, és karbantartási ajánlat;

- a meglévő igazgatási-szervezeti megoldások megreformálása.

Mindez eröteljesebb kooperációt igényel mind regionális, mind nemzeti szinten az állami vagy magán szolgáltató intézményekkel, fejlesztési társaságokkal, szövetségi hatóságokkal stb.

Mint ismeretes, a magyar helyi tanácsok alig rendelkeznek támogatási célú pénzeszközökkel, söt maguk vannak a támogatásra rászoruló helyzetében, különösen a községekben. A településekre visszajuttatott adón feluli, az ugyancsak a gazdálkodó szervektôl származó eszközök a „,koordinációs bevételek” elnevezést viselik, noha a tanácsok hatása a támogatók nyereségességére teljesen névleges, nemhogy a telepítést és/vagy általa adott település gazdasági struktúráját érdemben befolyásolják. „A legnagyobb probléma, hogy e bevételi forrásért folytatott kijárás teret enged a ,szocialista virilizmusnak".,4

A Tanácstörvény 1985-ös módosítása némi változást sejtet. A tanácsok elvi lehetőséget kaptak vállalatok és intézmények létrehozásán túl gazdasági társulásban való részvételre, továbbá a gazdálkodásuk egésze módosult. Mindenesetre elgondolkoztató, hogy miért csodálkozunk addig azon, hogy a koordináció kevés érdemi tartalommal bir, amíg azt egyol- dalú képletben (a tanács kiszolgáltatottságát prezentálva) képzeljük el, amíg az együttmûködés szinte kizárólag pénzben manifesztálódva jelent értéket számunkra.

Citálásra érdemes az osztrák Norbert HaryThomas Jeinze szerzőpáros elōadásának számos eszmefuttatása. A területi tervezést állítják egy költségcsökkentő program szolgálatába, mondván, a hagyományos eszközök (bevételek növelése, kiadások csökkentése stb.) nem érik el a kívánt hatást. Lényegében egy takarékosabb szemléletü ter ületfejlesztési, illetve rendezési politikát javasolnak. Emögött az az egyszerû́ tény húzódik, hogy Ausztria legtöbb községe ma hosszabb távon stagnáló bevételekböl kényszerül gazdálkodni. Hary és Heinze tételes megálla pításai egyrészt, hogy közvetlen összef üggés van a településfejlödés minösége és a község költségvetési mozgástere között, másrészt minél magasabb a település fejlettségi szintje, annál alacsonyabb a magánháztartások és az üzemek infrastrukturális költségterhelése. A településfejlesztés minőségén a használati konfliktusok és a környezetterhelés minimalizálását kell érteni bizonyos kommunális feladatok ellátásában. A szerzök állításaikat egy általuk 5-P-nek elkeresztelt programmal igazolják. Alapja a községi gazdálkodás hétköznapi példája: A községi területrendezési tervbe ${ }^{5}$ felvett beépíthető földter ületek egyszeri és további infrastrukturális költségeinek minimalizálása a parcellák ésszerü, utat, csatornahálózatot stb.-t lerövidítố kijelölésével.

$\mathrm{Az} 5$-P program célja ennek eredményeként a községi ,játéktér" kitágítása és a magánháztartások, valamint az üzemek terhelésének csökkentése. A program öt analitikus tervezési és döntési lépcső́t állít fel:

1. Portfolio-analízis (mint a településfejlesztés minősége és a községi mozgástér optimális eredójének meghatårozása).

2. Tervkorrekció (alapja a községek már meglévô és felülvizsgálatra szoruló ter ületfelhaszrálási terve).

3. Programköltségvetés

4. Publikus reláció (mint a községi polgárok informálása).

5. Magánkezdemén yezések (a családoknak és üzemeknek a gyakorlatban való hozzájárulása a takarékossági programhoz).

(A számok nem jelölnek sorrendiséget.)

Mindenesetre elgondolkoztató, hogy a nálurknál gazdagabb országok a lega próbb réseket 
is megkęresik és megtalálják a takarékosabb gazdálkodásra, addig mi legfeljebb a kényszer hatása alatt tudjuk a racionalitás stratégiáját választani.

A helyi-települési feladatok között újdonságként fog megjelenni a jövóben a foglalkoztatáspolitika Magyarországon. A gazdaság múködésének hatékonyságát célzó szerkezetátalakítás elkerülhetetlenné teszi a strukturális munkanélküliséget. Az ellensúlyozó kezdeti lépések már megtörténtek (,,közhasznú munkavégzés", Központi Foglalkoztatáspolitikai Alap, elhelyezkedési támogatás). A munkanélküliség azonban (magyar és osztrák tapasztalatok egyaránt bizonyítják) területileg differenciáltan jelentkezik. Hazánkban föleg a hagyományos nehézipari megyékben létrejött ún. depressziós térségek, Ausztriában a kevés és kedvezótlen munkahelykínálatú üzemmel, valamint magas agrárkvótával rendelkezó periférikus zónák mutatják, hogy a kérdés kizárólag központi szinten nem oldható meg. A hasonlóságok mellett a küiönbség abban áll, hogy míg Ausztriában már a községeknek is van foglalkoztatáspolitikai stratégiája, addig Magyarországon a küszöbön álló lépés, hogy a ter ületi szintet a foglalkoztatási érdekek megjelenési fórumává tegyük.

Dieter Keil elóadása a tartós munkanélküliség össztársadalomra gyakorolt negativ hatásainak vizsgálatát vállalja fel. Ertékelését azonban községi szintre is kivetíti. Számot vet, többek között, a demográfiai következményekkel. Az utóbbi elvándorlás és csökkenő születési arányszám útján minőségi népességvesztéshez, illetve a községek jövedelemrészesedésének csökkenéséhez vezet. $\mathrm{Az}$ eredmény gazdasági krizis.

Nyilvánvaló a kontraszt, ami a munkaerőpiac, a gazdaságpolitikai fejlődés községi szintet terheló tényezói és a községek korlátozott cselekvési lehetôsége között fennáll. Ơngerjesztố spirál jön létre. Ahogy nô a munkanéłküliek tömege, úgy csökken a hełyi önkormányzat adóbevétele és mozgástere, foglalkoztatási színvonalat emelổ eszközrendszere. Keil az ellentmondás feloldására a községi gazdaságpolitika, valamint a munkaerópiaci régiók lehatárolása mellett teszi le voksát.

A tanácskozáson több elóadás foglalkozott a munkanélküliséggel. $E$ tény magától értetödő, ha figyelembe vesszük, hogy a nyugati társadalmak egyik neuralgikus pontjáról van szó.

Ernst Knoth (a KDZ tudományos munkatársa) a foglalkoztatás kiszélesítésének alternativáját vázolja fel. Mindenekelótt érzékeli, hogy az egyszer majd általánossá váló munkaidőssökkentés bevezetésének időpontja bizonytalan. A harmincöt órás munkahetet nemcsak községi, de nemzetgazdasági szinten is kockázatosnak véli, még egy vezető ipari államban is.

A járható út a munkaidô-politika és annak foglalkoztatáspolitikai hasznosítása - állapítja meg -, nem pedig az extenziv foglalkoztatás. Munkaidö-politikán a meglévó munkalehetôség költségkímélö újrafelosztását érti. Ennek három variánsát boncolgatja. Rövidtávon elsósorban a túlórák helyett a pótlólagos foglalkoztatást javasołja. A részmunkaidóben való foglalkoztatás a másik lehetöség, amely azonban a létszükségletet fedezó jövedelemmel kell, hogy együtt járjon. A munkaátrendezés harmadik lehetősége a szolgálat alóli átmeneti mentesítés (Sabbatjahre).

$\mathrm{Az}$ elóadássorozat önmagáért beszél, a kiemelések legfebjebb megszakíthatók, de be nem fejezhetôk. Szembeötló, hogy Ausztriában és az NSZK-ban a felvetett problémák megoldását nem vagy nem elsősorban központi szinten keresik, és nem az adminisztratív eszközök dominanciájával. A kindulópont a helyi adottságokhoz történô alkalmazkodás, az alulról építkezés a helyi stratégia kialakítása céljából. Másrészt a foglalkoztatáspolitika súlya arra figyelmeztet bennünket, mintha ,ott" szociálisan még mindig érzékenyebbek lennének. 
1. A községfogalmat nem mint közigazgatási településkategóriát, hanem mint a helyi önkormányzat összefoglaló nevét (városra, községre és községszövetségre egyaránt vonatkoztatva) fogom használni.

2. Idézte Wahl, Hermamn: Finanzzuweisungen an die Kommunen als Instrument der staatlichen Konjunkturpolitik, Berlin 1980. 104.S.

3. Schnur, Roman: Abgrenzung der Gemeindlichen Aufgaben von den Aufgaben der
Kreise gemäß Art. 28 Abs. 2 GG.Die Verwaltung, 1986/1.sz.

4. Verebélyi Imre, Tanácsi gazdálkodás és helyi önállóság: kerekasztal beszélgetés. Társadalmi Szemle, 1083/7.sz.

5. A területrendezési terv(ezés)ként lefordítható „örtliche Raumplanung" Ausztriában összetett fogalom. Felöleli a területfelhasználási tervet, a beépítési tervet, valamint a helyi fejlesztési koncepciót. 